ARCTIC

VOL. 65, SUPPL. 1 (2012) P. 136-152

\title{
Cultural Landscapes, Past and Present, and the South Yukon Ice Patches
}

\author{
SHEILA GREER ${ }^{1}$ and DIANE STRAND ${ }^{2}$
}

(Received 22 February 2011; accepted in revised form 23 November 2011)

\begin{abstract}
South Yukon First Nations governments are partners in the Yukon Ice Patch Project investigating the mountaintop snow and ice patches where ancient hunting artifacts are being recovered. Heritage programs operated by these governments, which coordinate their citizens' engagement in these activities, emphasize intangible cultural heritage. They view the project as an opportunity to strengthen culture, enhance citizens' understanding of their history, and express First Nations values regarding cultural resources. As the primary mammal subsistence species for south Yukon Indian people is now moose, the ice patch discoveries highlight the historical role of caribou in their culture and increase awareness of the environmental history of their homelands. The cultural landscape concept is used to frame the present indigenous involvement in the Yukon ice patch investigations, as well as the past use of these unique landscape features and ancient land-use patterns. The Yukon Ice Patch Project reflects the contemporary context of the territory, where indigenous governments are actively involved in managing and interpreting their cultural heritage.
\end{abstract}

Key words: First Nations, self-government, land claims, partnerships, Tutchone, Tagish, Tlingit, heritage, history, intangible heritage, social context, caribou, hunting, subsistence, artifacts, precontact land use, cultural landscapes

RÉSUMÉ. Les gouvernements des Premières Nations du sud du Yukon figurent au rang des partenaires du projet des névés du Yukon, dans le cadre duquel des chercheurs font des fouilles dans les névés de sommet de montagnes où d'anciens artefacts de chasse sont retrouvés. Les programmes du patrimoine administrés par ces gouvernements, qui coordonnent la participation de leurs citoyens à ces activités, mettent l'accent sur le patrimoine culturel immatériel. Aux yeux de ces gouvernements, ce projet constitue une occasion de renforcer leur culture, de faire en sorte que les citoyens connaissent mieux leur histoire et d'exprimer les valeurs des Premières Nations en ce qui a trait aux ressources culturelles. La principale espèce de subsistance des Autochtones du sud du Yukon est maintenant l'orignal, mais les découvertes des névés font ressortir le rôle historique du caribou au sein de leur culture et leur font connaître davantage l'histoire de leur environnement. On se sert du concept du paysage culturel pour encadrer la participation actuelle des Autochtones aux fouilles des névés du Yukon ainsi que pour définir l'utilisation passée de ces caractéristiques uniques du paysage et des anciennes tendances d'utilisation des terres. Le projet des névés du Yukon reflète le contexte contemporain du territoire, où les gouvernements autochtones s'adonnent à la gestion et à l'interprétation active de leur patrimoine culturel.

Mots clés : Premières Nations, autonomie gouvernementale, revendications territoriales, partenariats, Tutchoni, Tagish, Tlingit, patrimoine, histoire, patrimoine immatériel, contexte social, caribou, chasse, subsistance, artefacts, utilisation des terres avant le contact, paysage culturel

Traduit pour la revue Arctic par Nicole Giguère.

\section{INTRODUCTION}

The story of the enduring relationship between caribou and ancient people in the southern Yukon, Canada, is being brought to light by the discoveries at ice patch archaeological sites. "Long-ago peoples" recognized these mountaintop locales as places where they could hunt caribou. Now, as the patches melt and shrink with the warmer summers of recent decades, the First Nations of the southern Yukon are partners in the Yukon Ice Patch Project. Their citizens (or members, or beneficiaries; varying terms are used and different categories recognized) are recovering hunting tools lost over the millennia by their cultural predecessors and, along with their governments, interpreting the meaning of these finds and the sites for their people today.

The Yukon ice patch sites are yielding archaeological specimens and valuable paleoecological data that are unparalleled in the North American Subarctic (cf., Farnell et al., 2004; Hare et al., 2004, 2012). Here we examine the social and cultural context of the south Yukon ice patch investigations, considering the ice patch sites as part of ancient and contemporary "cultural landscapes."

The geographer Carl Sauer is credited with clearly formulating the cultural landscape concept (Sauer, 1967,

\footnotetext{
${ }^{1}$ Champagne and Aishihik First Nations, Heritage Program, and Research Associate, Canadian Circumpolar Institute, University of

Alberta; mailing address: Box 5374, Haines Junction, Yukon Y0B 1L0, Canada; sgreer@ualberta.ca

${ }^{2}$ Champagne and Aishihik First Nations, Heritage Program, Box 5310, Haines Junction, Yukon, Y0B 1L0

(C) The Arctic Institute of North America
} 
2009). Anthropologists and archaeologists quickly recognized its utility for understanding present and past relationships between people (human societies) and their environment (e.g., Basso, 1996; Ingold, 1996; Ashmore and Knapp, 1999). Governments and organizations tasked with protecting or commemorating heritage (Rössler, 2003) began to embrace the "cultural landscape" concept in the 1990 s, with an early application in a northern Dene context (Hanks, 1993, 1996). Government agencies responsible for the commemoration of Aboriginal history in Canada have argued that the cultural landscape concept provides a framework for understanding Aboriginal history in Aboriginal terms (Goldring and Hanks, 1991; Buggey, 1999, 2004; Parks Canada, 2012). The Northwest Territories has a formal program to designate Aboriginal cultural landscapes (cf., Andrews, 2004; Government of the Northwest Territories, 2007). No such program exists in the Yukon, though Aboriginal values toward place are considered in the protected areas planning process.

In examining Aboriginal cultural landscapes, we set aside the matter of their national or territorial significance and focus instead on cultural landscapes that are significant to the First Nations involved in the Yukon ice patch studies. These indigenous governments delineate their modern-day cultural landscapes by the boundaries of their respective traditional territories (Fig. 1). We are also concerned with the ancient cultural landscapes of the past users of the Yukon ice patch sites, recognizing that at the time of their use, these locales did not exist in isolation.

After providing environmental and social context on the ice patch study area, we introduce the six First Nations involved in the Yukon Ice Patch Project, the Yukon Land Claims process and the heritage programs operated by Yukon indigenous governments. We further frame the contemporary social context by considering indigenous perspectives of history and what has been learned about caribou in their history, expanding upon a previous brief discussion of this topic (Hare et al., 2004).

Having reviewed the contemporary cultural landscape within which the First Nations understand the ice patch sites, we consider the ancient cultural landscapes that the ice patch sites were part of when they were being actively used. We consider the spatial relationship between the ice patch and other local archaeological sites, as well as the insights into precontact land-use patterns that these data provide. Returning to today's times and contemporary meanings, we report on the First Nations participation in the investigations and their interpretations of the finds and consider their motivations for involvement in the Yukon ice patch studies. These indigenous governments strongly emphasize "intangible" cultural heritage (cf., UNESCO, n.d.), viewing the project as an opportunity not only to express cultural values and strengthen culture, but also to enhance their citizens' understanding of their history and the environmental history of their homelands.

The discussions presented here therefore complement the contribution of Hare et al. (2012), who report on the Yukon ice patch sites and the artifacts and samples recovered from these unique landscape features.

\section{Clarifications and Cautions}

Some points of clarification are necessary before embarking on our review of the cultural landscape and social context of the Yukon ice patch investigations. We use the phrase "ice patches" as an abbreviated version of the more accurate descriptor, "ice patches with dung." The mountains of the southern Yukon have innumerable snow and ice patches, but only those that feature dung, believed to be largely caribou dung, have yielded the ancient hunting artifacts that are the focus of the Yukon ice patch studies. As noted by Hare et al. (2012), nearly 100 ice patches with dung have been documented in this region. To date, 24 of these have yielded artifacts, which allows these unique paleoecological sites to be registered also as archaeological sites.

Additionally, although this paper focuses on Yukon sites, we note that ice patches with dung also exist in adjacent northernmost British Columbia. They have been confirmed within the British Columbia portion of the Champagne and Aishihik First Nations (CAFN) traditional territory (Greer, 2004a), as well as in the traditional territory of the Taku River Tlingit in the Atlin area (French and Greer, 2007, 2008). However, no dung-bearing ice patch in these areas has yet yielded artifacts.

Further, while we present insights on the history and traditional land-use patterns of the six First Nations involved in the Yukon ice patch work and on the significance of their participation, the information and interpretations presented here are those of the authors. They do not necessarily represent the views of the indigenous government with which we are associated or the other First Nations discussed. Nonetheless, following Yukon First Nations tradition (cf., Cruikshank, 1981), we think it appropriate to indicate the authority from which we speak. The lead author (Greer) has worked for or with most of the First Nations governments that are part of the Yukon Ice Patch Project, as well as with many individual members of these same communities, and has many years of archaeological experience in the ice patch study area. At the time of writing, Greer is also research coordinator for the "Ice Patch Community Dimensions Project," coordinated by the Ta'an Kwäch'än Council. Strand was employed as Heritage Officer for the Champagne and Aishihik First Nations for more than a decade, organizing the involvement of all the nations in the project in the years from the initial discovery in 1997 until 2006. She held the office of Chief of her First Nation between 2006 and 2010, and at present she manages her First Nation's Da Ku Cultural Centre. It is because of these affiliations that we speak in the first person (e.g., "our" history, rather than "their" history) in this paper.

The Ice Patch Community Dimensions Project, with financial support from the Northern Strategy Program (Government of Canada and Yukon Government), is 


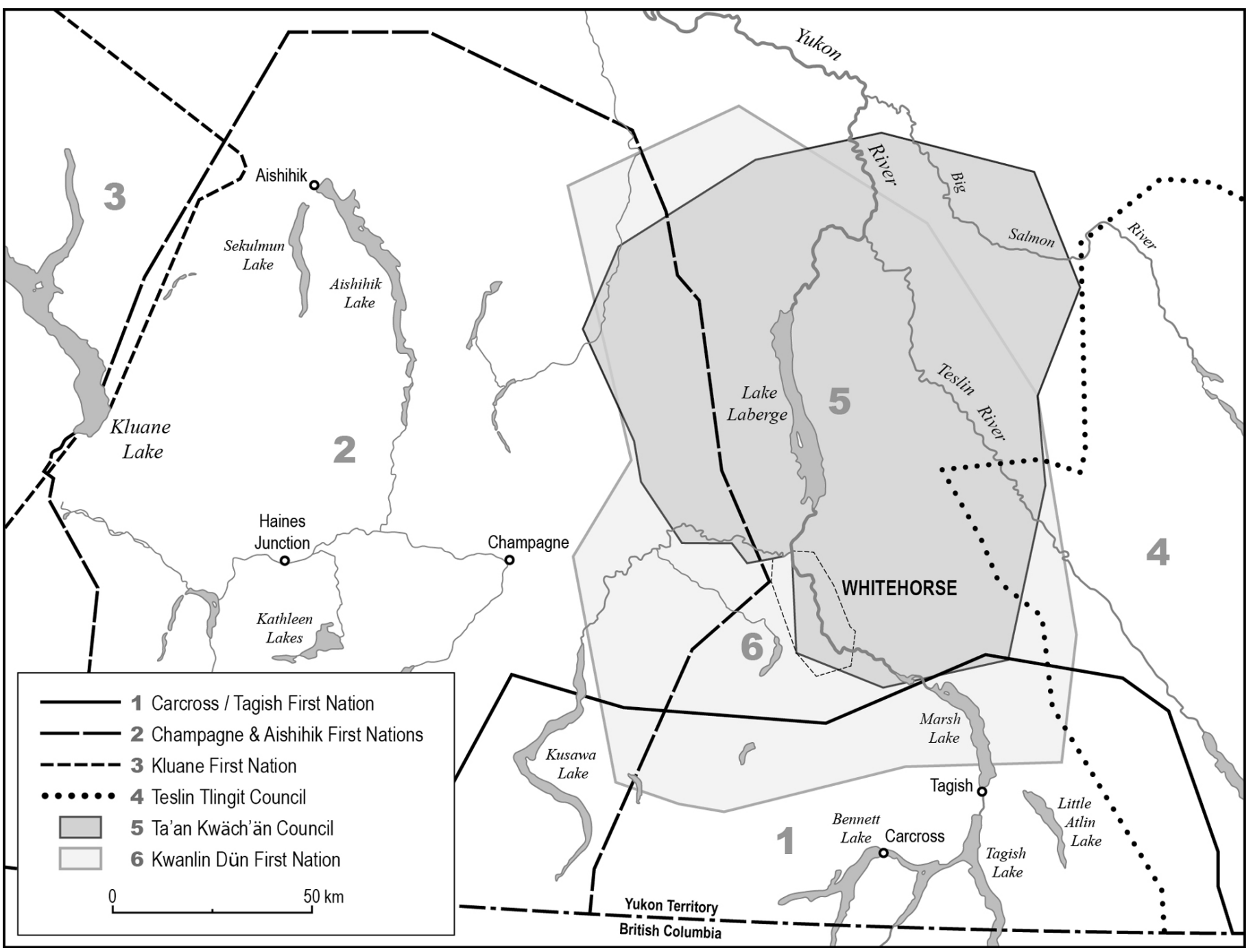

FIG. 1. Locations of the traditional territories of the six First Nations involved in the Yukon ice patch research.

providing an opportunity for each of the six participating First Nations to document community traditional knowledge relevant to the ice patch project. This knowledge includes information related to caribou, the use of the alpine landscape, and the artifacts being recovered from the ice patch sites, and its documentation is ongoing. The present paper is based largely on oral history and traditional knowledge information in published or archival sources, rather than on unpublished data held by the First Nations governments.

\section{ENVIRONMENTAL CONTEXT}

The ice patches are located in the mountainous plateau country of the uppermost Yukon and Alsek hydrological basins (Fig. 2). The patches that have yielded artifacts are located between $60^{\circ}$ and $62^{\circ} \mathrm{N}$ (the former representing the B.C. - Yukon boundary) and roughly between $134^{\circ}$ and $138^{\circ} \mathrm{W}$. Patches with caribou dung but no cultural remains extend over a slightly larger area. The southern Yukon ice patch study area has few roads and even fewer routes of access to the higher-elevation settings of the ice patches. It takes many hours of hiking to reach even the most accessible patches, and others can be reached only after several days of walking. Helicopter transport is now used to access the Yukon ice patches for research and educational purposes.

The patches that are archaeological sites occur in two clusters: a smaller one situated northeast of Whitehorse, the territorial capital (Fig. 2), and a larger cluster extending from the Carcross area in the southwest to a point north of Haines Junction and Kluane National Park to the northwest. These Yukon ice patch sites are inland from, or in the lee of, the higher rugged peaks of the Coast Mountains, which block much of the moist Pacific coast air from entering the upper Yukon basin. The climate in the ice patch study area is continental interior - generally dry $(250-300 \mathrm{~mm}$ annual precipitation), with long winters that include periods of severe cold and temperate summers with long daylight hours.

The valley bottoms in the ice patch study area are at ca. $600-900 \mathrm{~m}$ elevation, and the surrounding mountaintops, 


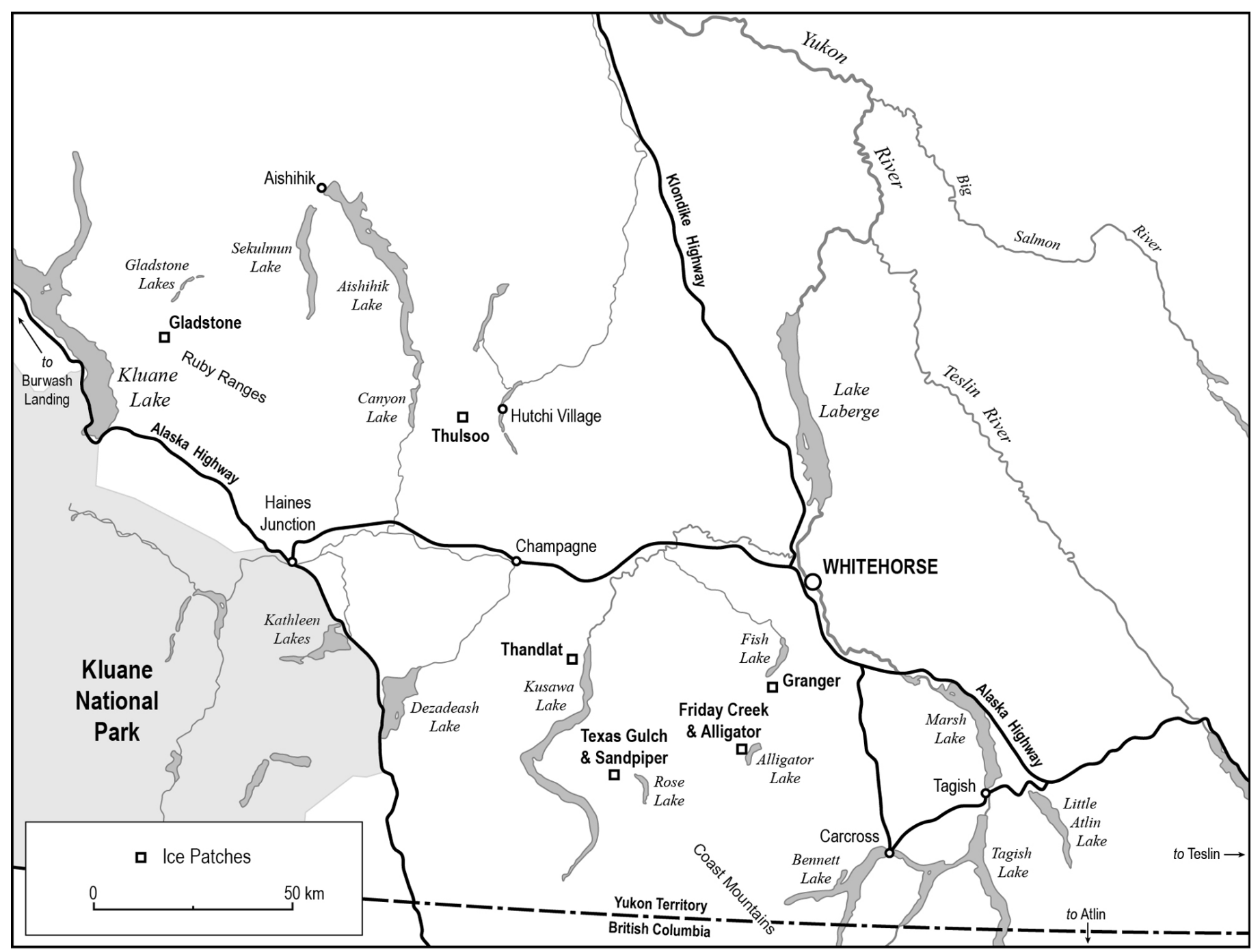

FIG. 2. Location of the Yukon ice patch research and localities mentioned in text.

ca. $1500-2300 \mathrm{~m}$ above sea level. This is the Northern Boreal Mountains Ecoprovince (Boreal Cordillera Ecozone), where white spruce (Picea glauca) is the dominant forest type. Black spruce (Picea mariana) and alder (Alnus crispa) are present as well, and pine (Pinus contorta) is found in the eastern part of the study area. The altitudinal tree line sits at ca. 1050-1200 m (Oswald and Senyk, 1977; Yukon Ecoregions Working Group, 2003). The ice patches themselves lie between ca. 1550 and $2075 \mathrm{~m}$ (Farnell et al., 2004).

Today, the southern Yukon features a fauna typical of the Subarctic cordillera. In addition to caribou, moose, mountain sheep, mountain goat, wolf, fox, black and grizzly bear, beaver, and porcupine, it includes a long list of small mammals (ground squirrels, hare, and various furbearers), as well as numerous bird and fish species (Youngman, 1975). Recently bison and elk, both present in the area in the early Holocene, have been reintroduced to the region. Remains of these two species, either skeletal or dung, have also been recovered from various Yukon ice patch sites (Farnell et al., 2004:255).
The ice patch sites with their quantities of caribou dung were a surprise for local biologists when originally discovered because caribou (woodland subspecies) are present only in low numbers or have been totally extirpated from the area where the ice patches are located (Kuzyk et al., 1999). The discoveries thus have provided evidence that the former range of the species extended beyond its present distribution (Farnell et al., 2004). DNA extracted from dung preserved in the ice patches is also helping to clarify the genetic history of Yukon caribou (Farnell et al., 2004; Kuhn et al., 2010). The "discovery" that caribou were formerly abundant in the southern Yukon, however, was not new to First Nations Elders or to those familiar with their oral history, as discussed below.

\section{SOCIAL CONTEXT: THE YUKON ICE PATCH FIRST NATIONS}

The Yukon ice patch sites are located within the traditional territory of six Yukon First Nations (Fig. 1). Finds 
since 2003 have increased the number of First Nations involved in the project from the previously reported four (Hare et. al., 2004). Listed from west to east, the six "Yukon Ice Patch First Nations" as the group is known, include the Kluane First Nation, based in Burwash Landing; the Champagne and Aishihik First Nations, Haines Junction; the Kwanlin Dün First Nation, Whitehorse; the Ta'an Kwäch'än Council, Whitehorse; the Carcross/Tagish First Nation, Carcross; and the Teslin Tlingit Council, Teslin (Fig. 1). These indigenous governments maintain their own websites. The Taku River Tlingit First Nation, based in Atlin, British Columbia, also participates in the Yukon Ice Patch First Nations group on an occasional basis.

Anthropologists and others have used linguistic differences to identify and refer to the Yukon's indigenous peoples. The Kluane, Champagne and Aishihik, Kwanlin Dün, and Ta'an Kwäch'än nations are typically described as being of Southern Tutchone cultural background. In Southern Tutchone, a language of the Athapaskan family, they refer to themselves as Dän (other spelling variants Dun, Dün, Dan), meaning 'person' or 'people.' While largely Dän, some families within these four nations also recognize and honour Tlingit ancestry. Tlingit derives from the word lingit, meaning 'person' or 'being' in the Tlingit language. The Teslin people similarly identify as Tlingit, while the Carcross/Tagish First Nation refers to its people as being of Tagish (also Athapaskan) and Tlingit cultural background.

Archival sources related to the history of all south Yukon Indians are limited. The period of written history began only in the 1890 s, when non-Native outsiders first arrived in their lands. The principal anthropological sources for information on the history and culture of these peoples, including collaborative accounts from indigenous perspectives and voices, are various works by Catherine McClellan (1975, 1981a, b, c; 2007a, b, c; McClellan and Denniston, 1981; McClellan et al., 1987). Other useful sources are Cruikshank (1974, 1979, 1982, 1984, 1985, 1990, 1991, 2005) and Cruikshank et al. (1990), O'Leary (1992), Jackson (2006), Thornton et al. (2004), and CTFN and Greer (1995).

Before outsiders arrived in the southern Yukon, both the Tlingit and the Dän were small-scale hunter-gatherer subsistence societies. Family groups lived by hunting and fishing, following seasonal rounds that involved a high degree of mobility, and "home" was seasonal villages or shorterterm campsites. Trade within and between the different peoples, including neighbours and relatives located outside of what is now the Yukon Territory, was an important component of pre-contact indigenous life. In the 19th century, fur trapping began to play a larger role in the lives of community members, and in the 20th century, permanent settlements began to develop. Pre-contact Aboriginal land-use patterns are further considered below.

Contemporary citizens of Yukon First Nations strongly identify with the hunting and fishing traditions of their ancestors and continue to practice them. Maintaining these ancestral ties to the land remains a priority for Yukon
Indian people and for the governments that represent them. While hunters now take some sheep and the occasional rare caribou, as well as some of the reintroduced bison and elk, and catch quantities of fish (salmon, whitefish, etc.) and small game, today moose rather than caribou is the primary large mammal species hunted in the southern Yukon. Both community oral history and archaeological data from the Yukon ice patch discoveries (Hare et al., 2004, 2012) document this regional shift in key subsistence species.

\section{First Nations Approaches to History}

The traditional stories of southern Yukon Indian people, in particular the Dän (Athapaskans) stories, suggest that our history is intimately connected to the Yukon landscape, with the Dän having lived here since Crow first "brought light to the world" (J. Fraser in McClellan, 2007a), and Animal Mother (also known as Moose Mother) "gave birth to all the animals" (M. Brown in McClellan, 2007a). Traditional stories, called kwädindür or kwädäy kwändür (Tlen, 1993; Workman, 2000), make no reference to major migration events in the past (cf., McClellan, 1975, 2007a; Sidney et al., 1979; Ned, 1982; Smith, 1982; Cruikshank et al., 1990; Workman, 2000; Allen, 2006; Jackson, 2006). These stories demonstrate familiarity with the land and the animals of the boreal forest interior of northwestern North America, with only passing reference to beings, places, and things situated outside this biogeographic context. There are also kwädindür that refer to the cultural hero Äsùya, sometimes called "Beaver Man," who made the land safe for people by getting rid of the dangerous animals. The Äsùya stories may refer to the megafauna that were present in the territory during ice age (Pleistocene) times (cf., Harington, 1978; Zazula and Froese, 2011).

Tlingit history begins in similar way, with Raven fixing and transforming the world. After that long-ago point in time, Tlingit history emphasizes the origin stories of the various clans that together constitute Tlingit society (cf., Hope and Thornton, 2000; Thornton et al., 2004; see also Patsy Henderson, Billy Smith, and Angela Sidney in McClellan, 2007c). Individual Tlingit clan histories document the ancient movement of their people down a river, or a river blocked by glacial ice, from the interior to the coast of southeastern Alaska. Though their history may connect the various Tlingit clans to the coastal regions of adjacent Alaska, as the Teslin Tlingit have noted on their website, their roots in the Yukon nonetheless extend back to a time before local written history. Some of the traditional stories of the Carcross/Tagish people (cf., McClellan, 1975, 2007b; Sidney, 1980, 1982; Cruikshank et al., 1990) likewise suggest a long-term familiarity with their present Yukon homelands.

\section{Caribou in South Yukon First Nations History}

Today, caribou occur in extremely low numbers, and the species is protected across most of the Yukon ice patch study area, being hunted only in the Aishihik Lake region (Fig. 2). 
The ice patch discoveries (Farnell et al., 2004; Hare et al., 2004) triggered the process of remembering and bringing forward the relationship between people and caribou.

Caribou-mäzi or $u d z i$ in Southern Tutchone; wejih in Tagish, and watsix in Tlingit (CTFN et al., 2002) - are noted in the traditional stories of the local First Nations. They are frequently mentioned in Dän kwädindür and in Lingit Tlagu (traditional stories) set in the long-ago time when animals and humans could talk together (Kitty Smith in Sidney et al., 1979:76, 85; Smith, 1982:19, 28, 64, 105; Peters in McClellan, 2007c).

Caribou also feature in traditional stories of more recent vintage. We present an extract from one such account here to illustrate the insights that can be gained from such sources. The story, told by Elder Frances Joe, recounts a local tragedy that occurred in the Dezadeash Lake area of the Champagne and Aishihik First Nations traditional territory in late precontact times, not long before outsiders arrived here (McClellan, 1975; Greer, 1997). The tragedy happened when strangers attacked a local Dän camp, causing many deaths. The attackers had dressed in caribou skins to disguise themselves as they crossed the frozen lake to reach the camp of their victims.

\section{Dezadeash too, there was herds of caribou through there.... That was the year the massacre happened there. They saw them coming across. Most of the people that were there, they were from Dalton Post. They said "Oh look at the caribou coming across," [but] it was people. They stayed in bunches...tried to be caribou... They didn’t suspect anything. (Frances Joe, 2009)}

The story detail about the disguise informs the listener that caribou were common in this setting (Dezadeash Lake) at the time of the attack (later winter to early spring), thus providing information on the species' seasonal presence and distribution. There are also more direct accounts, such as that from Mrs. Annie Ned (in Cruikshank et al., 1990:299), which refers to the Kusawa Lake area in the 1930s:

There used to be lots of caribou, even in my time. When caribou came, it was just like horses. You could hear it [hooves] making noise on the ice.

Certain Aboriginal-language place names, or more accurately the stories associated with such toponyms, include content about caribou, such as a place in a lake where whirlpools or waves drowned a group of the animals (Smith, 1982:98). Accounts about traditional lifeways, such as that found in Allen (2006), include information about hunting of the species. Some stories refer to caribou as being an individual's "medicine" or power (Smith and Ned in Cruikshank et al., 1990; Peters in McClellan, 2007c).

Caribou are also mentioned in stories of 19th-century trade that took place between the Dän and Tagish and their Tlingit neighbours from the adjacent coast of southeastern Alaska. These stories indicate that coastal residents highly valued the caribou skin clothing made by the interior people and that both finished clothing and skins were important trade items during this period (Ned in Cruikshank et al., 1990:280). Caribou hides in particular were highly valued for the making of shirts and trousers owing to their fine texture and durability. An anthropologist who interviewed residents of Klukwan, Alaska, in the early 20th century was told that before European clothing became available, all Tlingit villages in southeast Alaska provided a ready market for prepared caribou hides (Oberg, 1973:108).

Some documentation exists on traditional south Yukon Aboriginal caribou hunting (cf., McClellan, 1975, 2007a, b, c; CAFN et al., 1999). We know that the species was taken year-round, using a range of techniques, depending on the season and setting. Snares were set individually or in hunting fence complexes, and weapons, such as the arrows being found at the ice patch sites, were also used to take down the animals. In some settings, hunting blinds were used to conceal hunters, and blinds have been identified around some of the south Yukon ice patch archaeological sites.

Neither oral history records nor traditional knowledge research by the six First Nations has yet encountered a large body of information specific to ice patch hunting. The reasons for this gap are not fully understood. Perhaps it exists because caribou are absent from most parts of the study area, or because land-use patterns have changed since the 1930s, when caribou were last locally abundant. Possibly it is because hunting at ice patches played only a small role, overall, in the traditional subsistence economy. Any of these situations might have meant that the information was not considered relevant enough to pass on to younger generations. Alternatively, it could simply be that hunting at the ice patches is not very different from any other type of hunting conducted above the altitudinal tree line.

Notwithstanding the lack of oral history on hunting at the ice patches, many references to hunting in the alpine setting in general can be found in CAFN oral history transcripts. Older archival sources that refer to this topic are few in number, however. We have found only one early traveler's account (Glave, 1892) that mentions south Yukon Indians reporting wildlife at higher elevations during the hot summer months and one archival reference (Schwatka, 1996) that specifically mentions Yukon Indian people intentionally seeking out and hunting caribou on snow or ice patches in the summer. The latter source refers to a hunting event that took place in the 1880 s to the north of the southern Yukon ice patch study area, in the mountains west of Fort Selkirk and Pelly Crossing and south of Dawson City. The Schwakta reference illustrates that summer hunting of caribou on mountaintop snow or ice patches was a widespread practice, while at the same time reminding us that the southern Yukon ice patches with dung are not the only places where hunting caribou on mountaintop snow or ice occurred. Rather, the ice patches are the locales where evidence of this widespread practice has been preserved by the semi-permanent snow and ice that covers the mountaintops. 
While we are certain that caribou were an important species to south Yukon Indian peoples in earlier times, their overall significance, and how this might have varied over time, remains unclear. We do not know whether caribou represented a cultural keystone species for southern Yukon people (cf., Garibaldi and Turner, 2004) as they historically have for the Gwitchin (also spelt Gwich'in) of the northern Yukon and adjacent Alaska and Northwest Territories (Slobodin, 1981).

\section{First Nations Heritage Programs}

All six of the Yukon First Nations involved in the Yukon ice patch investigations have successfully negotiated landclaim agreements in the past 15 years (e.g., Government of Canada et al., 1993). These tri-party modern-day treaties, between the governments of Canada, Yukon, and the First Nation, specify the rights and responsibilities of the different governments. The agreements clarify matters such as taxation and First Nations ownership of large blocks of land within their respective traditional territories, and they ensure First Nations representation on various co-management boards that deal with such matters as fish and wildlife, water resources, and land-use planning. The related self-government agreements guarantee First Nations lawmaking authority within specific areas of jurisdiction, and the laws that they proclaim override the existing territorial or federal legislation.

The Yukon land-claim agreements include a chapter (\#13) that deals specifically with heritage matters, providing guidance on the rights and responsibilities of the three governments regarding the research, management, and interpretation of heritage. The chapter outlines the ownership and management of heritage resources, both moveable (e.g., artifacts, documentary resources) and non-moveable (e.g., heritage sites, trails), as well as the naming of geographic places and the use of First Nations traditional knowledge in heritage research and interpretive efforts.

Most Yukon First Nations governments that have settled their land-claim agreements have established formal heritage programs as the vehicle for fulfilling their Chapter 13 heritage rights and responsibilities. These operations employ anywhere from one to perhaps 10 or more staff members, as well as contractors. Some of the heritage workers have formal training in disciplines such as anthropology, archaeology, or history, while others might be recognized for their culturally based skills, knowledge, and training.

In years since they have been operating (from 5 to 15 years depending on the First Nation government), the Yukon First Nations heritage programs have placed a strong emphasis on "living heritage." These programs, recognizing the important role that heritage (or awareness of one's heritage) plays in constructing cultural identity and maintaining healthy lifestyles for their citizens, have targeted many activities and programs towards their youth and Elders. They commonly host "culture camps," where First
Nations youth spend time out on the land with community Elders, learning traditional bush skills such as gaffing salmon, setting fish nets or rabbit snares, hunting bison, or building traditional "brush camp" shelters. Cultural values and traditions are also passed on during these sessions.

These heritage programs also involve other activities related to First Nations history and culture, such as documenting oral history, traditional knowledge, and historic and contemporary land use; researching toponyms and genealogy; studying material culture, including traditional skills and art forms; and stabilizing and restoring heritage buildings (Greer, 2004b). Such programs may also be involved in preparing management plans for heritage sites and special areas such as national or territorial parks, as well as developing policy in many of the topic areas mentioned. The Ta'an Kwäch'än Council, for example, maintains an online database of indigenous-language toponyms and has had an individual, Chief Jim Boss, nominated as a "National Historic Person." Heritage staff of the various governments share information and have established the "Yukon First Nations Heritage Group" to address issues of common concern.

All of the nations are involved in cultural interpretation and educational outreach activities. The latter may be local, such as presentations in the local school, or geared to a more distant audience. Since 2006, the Teslin Tlingit Council has been operating a Culture Centre, where their culture and history is highlighted and presented to their citizens and the wider public. The Champagne and Aishihik First Nations and the Kwanlin Dün First Nation are now building similar institutions, and the Carcross/Tagish First Nation has plans for a comparable development.

The Ice Patch First Nations have experience with archaeology, particularly studies done in the context of development assessment. The ancient material culture recovered by archaeological field studies, including the ice patch research, is typically viewed as one of many ways of knowing and connecting to their peoples' history and culture.

By recognizing "living heritage" as a priority, the Yukon First Nations are focusing on what has been termed "Intangible Cultural Heritage" (ICH) (cf. Heritage Foundation of Newfoundland and Labrador, 2008; Smith and Akagawa, 2009). As characterized by UNESCO (n.d.), ICH refers to the traditions or living expressions inherited from one's ancestors and passed on to one's descendants. It can include oral traditions, performing arts, social practices, rituals, festive events, knowledge and practices concerning nature and the universe, or the knowledge and skills to produce traditional crafts. The Yukon First Nations are taking an active role in documenting their $\mathrm{ICH}$, in recognizing and celebrating it, and in ensuring that it gets passed on to future generations (cf., Heritage Foundation of Newfoundland and Labrador, 2008). In some cases, they are also exploring their ICH as a resource for community development.

In focusing on the intangible, the Yukon First Nations approach to history is not unique, but rather a common 
experience with Canada's Aboriginal peoples, as those involved in the commemoration of Aboriginal history have discovered.

[w] hat distinguishes Native Peoples' understanding, however, is the extent to which the human relationship with places has ethical, cultural, medicinal and spiritual elements, which are interwoven with patterns of economic use. Stories are told about particular parts of the land, spiritual powers exist in certain places, which are absent elsewhere, and teachings are annexed to specific places in ways that have little counterpart in non-Native society. In Native cultures, these attributes are often more important than the physical, tangible remains of past human use of land.

(Goldring and Hanks, 1991:14)

\section{FIRST NATIONS INVOLVEMENT IN THE ICE PATCH PROJECT}

While much of their heritage programming focuses on Intangible Cultural Heritage, the Ice Patch First Nations have nonetheless embraced the tangible dimensions of their peoples' past as evidenced in the Yukon ice patch archaeological discoveries. Still, in their involvement we see a strong emphasis on the intangible aspects of heritage, that is, a focus on the relationships between their people and old places and old things (for example, "this antler hunting arrow came from a site in the area where grandpa so and so used to hunt"). The intangible aspects of heritage are also emphasized in the stories: "One time so and so was hunting in this area, and he couldn't get down from the mountain, so [he] ended up spending a long night high up on a rocky ledge." All of this takes place within the context of their respective "cultural landscapes," meaning the traditional territories. These First Nations governments understand that they have a stewardship responsibility for these lands that they inherited from their ancestors; this would include taking care of their old cultural sites.

The First Nations have been actively involved in the Yukon ice patch research since the first ice patch with dung was recognized late in the summer of 1997. The initial ice patch find was made in the traditional territory of the Champagne and Aishihik First Nations (cf., Kuzyk et al., 1999). The First Nations' Heritage program quickly recognized the significance of that ancient artifact find, as well as the potential of the ice patches with dung to illuminate both the cultural and the natural history of their homelands (Farnell et al., 2000).

The role of the First Nations in the ice patch project has varied somewhat over the years, with a number of factors influencing where and how the various nations have engaged. These factors include the funding support for the project (both the amount provided and the organization in receipt of the funding), as well as the available staff resources the nations could direct to the project. In the early years of the ice patch investigations, only one First Nations government (CAFN) had heritage staff that could participate or facilitate the involvement of citizens. Efforts were nonetheless made to involve citizens of all the Ice Patch First Nations in project activities. Then, as more ice patches were discovered over a wider area of the southern Yukon, more First Nations governments became formally involved.

In 1998 and 1999, the ice patch fieldwork was largely a survey effort, focused on inventorying patches with dung and collecting artifacts, specimens, and samples from the surface (Hare et al., 2004). During that period, staff and citizens of the First Nations acted as fieldwork assistants for the project under the leadership of Yukon government staff archaeologists and biologists, and co-operating university researchers.

For the 2000 and 2001 field seasons, the First Nations secured project financing, which permitted them to take the lead in the fieldwork effort (CAFN et al., 2001). A full First Nations crew operated, providing training in fieldwork methods. The materials collected were turned over to Yukon Government departments (Heritage and Renewable Resources) that have the staff and program support to deal with conservation treatment, curation, and analysis - a practice that continues today. During both of these years, science camps operated in conjunction with the ice patch fieldwork (CAFN et al., 2001). This outreach initiative exposed First Nations youth to the science happening in their traditional territories, improving their understanding of the scientific research process. As considerable field-based science occurs in the southern Yukon under government or university direction, the ice patch science camps also provided an opportunity for field scientists, many of whom are based outside the territory, to engage with the local community and build relationships.

In the years since 2001, the Yukon government has funded the helicopter support required for project fieldwork. Yearly monitoring of those ice patches that have been yielding artifacts has been the priority, but wider and more detailed searches for additional patches that might also be archaeological sites are also made when weather and melt conditions permit. Representatives of the First Nations participate in these late-summer visits to the ice patches and the search for specimens and samples. Science camps have been held on a more intermittent basis.

In 2004, representatives of the six Ice Patch First Nations, along with the Yukon government staff archaeologist and a journalist, undertook an extended visit, camping out for four days at Gladstone, the Yukon's largest ice patch. As most ice patch site visits are brief, lasting only a few hours at best, this unique opportunity allowed the group to see caribou using the ice patch on a daily basis. New sites were discovered, and numerous artifacts were collected during this exercise, demonstrating the productive potential of an extended fieldwork effort focused on a specific cluster of ice patches (CTFN et al., 2005). That same year, two First Nations citizens traveled to the Smithsonian Institution in Washington, D.C., to assist with research focused on 
identifying the feathers preserved on the ice patch artifacts (cf., Dove et al., 2005). In 2004, First Nations representatives gave a presentation on their involvement in the ice patch investigations at a workshop in Nova Scotia (Greer et al., 2011).

In 2006, more than 60 indigenous youth from across Canada visited one of the south Yukon ice patches. Hosted by the Champagne and Aishihik First Nations, the ice patch visit was one of the land-based learning activities provided for youth attending the week-long First Nations and Inuit National Science Camp. Camp participants and their chaperones assisted in the search for specimens and samples at the Thandlät ice patch, and many hiked back down to Kusawa Lake at the end of the day.

During the 2008 and 2009 field seasons, in addition to the usual site monitoring visits, we were also able to take more community members to some ice patches with the support of the Ice Patch Community Dimensions Project. This visit increased familiarity with the sites and finds and provided context for the ongoing interview work. Community members have also toured the ice patch artifact collection in Whitehorse. In 2008, CAFN and the Yukon Government jointly developed a Memorandum of Understanding (MOU) that outlined their respective roles and responsibilities in the ice patch project. A government-togovernment document, the MOU also outlined the parties' responsibilities to each other. More recently, in the fall of 2010, a Kwanlin Dün First Nation staff member presented a paper on the First Nations' involvement in the Yukon ice patch project at the "Frozen Pasts" conference held in Trondheim, Norway (Mombourquette, 2010). First Nations Heritage staff also contributed to a Yukon Government publication on the Ice Patch Project (Hare et al., 2011).

The First Nations have played a range of roles in the Yukon ice patch investigations, at times leading the work, at other times collaborating with Yukon government project efforts or being a co-operating partner. Our concern here is not to define the nature of the working relationship between the parties involved in the Yukon ice patch investigations, which is best described as dynamic in nature, but rather to provide a background for consideration of their motives for involvement. As stated in a joint newsletter released in 2005, the First Nations have indicated that they seek to bring together both the Western science and traditional knowledge perspectives on these discoveries and the history of caribou in their homelands (CTFN et al., 2005). They view the project as an opportunity to strengthen culture, express cultural values, and encourage citizens to understand their history and the environmental history of their homelands.

\section{CULTURAL LANDSCAPES AND LAND USE}

The Yukon ice patch sites have been recognized as providing the first evidence for ancient use of the southern Yukon alpine landscape (Hare et al., 2012). These unique sites did not exist in isolation, however, but would have been part of one or more ancient cultural landscapes. The material culture evidence allows us to consider the kinds of activities that took place at the ice patch sites and the local patterns of land use in ancient times.

\section{Material Culture Evidence}

The material culture recovered at the Yukon ice patch sites (Hare et al., 2012) is dominated by weaponry of the type used for hunting large mammals such as caribou and sheep. The ice patch sites appear to be localities to which people came specifically to obtain game.

Tools suggestive of meat processing, such as a knife handle or lithic biface pieces, which would have been used in butchering and meat cutting, are also present, though not abundant, in the ice patch artifact collection (Hare et al., 2012). The faunal remains recovered (e.g., bone and antler pieces) also suggest that minimal processing of the animals took place up at the ice patches. Perhaps the carcasses were simply cut into quarters in order to reduce the weight to be carried back down the mountain to camp. Though there are no data to confirm or deny this hypothesis, we note that is also possible that entire quarters of meat may have been cached in or around the ice, at least on a short-term basis.

"Shakat" is the Dän term for the traditional summer hunt, during which meat is collected and preserved for future use (Allen, 1994). The southern Yukon Tlingit similarly put up meat in the late summer (McClellan, 1975). Traditionally, the most common way of preserving meat for future use was to dry it, and production of "dry meat" was an important shakat activity. The meat was cut into thin strips and hung on wooden racks, with a smoky fire burning underneath to keep the insects off the hanging meat until a crust has formed on the strips. Once fully dry, this meat is easily transported, and in times past, when families moved camp frequently, this high-protein and extremely lightweight food was a critical resource. Because dry meat production requires wood for construction of the drying racks and as fuel for the fire, it is likely that this activity took place below the tree line rather than in the alpine setting of the ice patches.

In Alaska and the Northwest Territories, evidence for other types of alpine land-use activities, specifically small game hunting, has been recognized at ice patches with the recovery of material culture used in the snaring of ground squirrels (cf., Andrews et al., 2012; VanderHoek et al., 2012). But although south Yukon Indian people traditionally caught ptarmigan and snared ground squirrels and marmots (locally known as gophers and groundhogs, respectively) in the alpine setting (McClellan, 1975), no evidence of these subsistence activities has been found at the Yukon ice patch sites.

Interestingly, the Yukon ice patch artifact collection includes numerous sticks or stick fragments of varying lengths. These pieces, which archaeologists refer to as "manuports," exhibit no formal shaping, but are recognized 
as artifacts because they have been transported to the treeless settings of the ice patches. Some of the unmodified sticks exhibit blunting damage on one end, perhaps from use as walking sticks. Wood artifacts thought to be walking sticks have also been recovered from the Kwädāy Dän Ts'ínchị site, located about $80 \mathrm{~km}$ away in northwestern British Columbia (CAFN and Greer, in press). The Dän term for walking stick or staff is $t \ddot{u}$; the Tlingit term is wùtsàghâ or yùtsàghâ (Tlen, 1993; Leer et al., 2001).

Finally, we note that no evidence for housing structures or shelters has been found at or around the Yukon ice patch sites. This information, considered in light of the historic pattern of indigenous land use, in which hunters made day trips up the mountains to obtain game, suggests that a similar pattern of land use was likely followed in times past.

\section{Land-Use Patterns}

To better understand the ancient cultural landscape within which the ice patch operated, we consider other evidence for ancient land use in the local area of the ice patch sites. Fortunately, the ice patches are located in the archaeologically better-known parts of the Yukon. Information in the Canadian Museum of Civilization (CMC) Sites Database, as well as unpublished manuscripts related to the investigations of such sites, allows us to consider the spatial relationship between the ice patch sites and other types of archaeological sites that have been documented in the study area.

As few of the lower-elevation sites discussed here have been investigated in detail, the data presented are preliminary in nature, as are the linkages made. The south Yukon ice patch sites or site clusters (Hare et al., 2012) and their associated valley-bottom archaeological sites are discussed from west to east (Fig. 2).

The first cluster we highlight is the group of ice patches in the Ruby Ranges, situated north of Kluane National Park, the Alaska Highway, and east of Kluane Lake (Fig. 1). The Ruby Ranges are today recognized as productive habitat and hunting area for sheep and moose. Small groups of caribou continue to frequent these mountains and have been seen at the Ruby Ranges ice patches during the height of the summer. Gladstone, the largest south Yukon ice patch, is located in the Ruby Ranges, as are smaller patches that have also yielded artifacts (Little Gladstone, East Gladstone, North Gladstone, Highfield, and Oakley). Roughly $10-15 \mathrm{~km}$ and a few hours' hike north of the Ruby Range ice patches is the Gladstone-Isaac valley system, a U-shaped mountain valley drained by creeks flowing southwest into Kluane Lake and northeast into Sekulmun Lake. Some of the Ruby Range ice patches can be seen from Gladstone Lakes, mid-point in the valley system. Well known as a traditional travel corridor through the mountains that separate Kluane and Sekulmun/Aishihik Lakes, the Gladstone-Isaac valley features numerous precontact era stone tool sites, many of which are located around Gladstone Lakes. The extent of the deposits and the nature of the lithic artifact finds suggest that these sites are campsites or base camps for hunting or fishing, rather than multifamily or more permanent village sites. We suggest that the Gladstone-Isaac valley sites may have functioned as the staging areas for various land-use activities in the surrounding mountains, including hunting trips to the Ruby Range ice patches.

The next ice patch we consider is represented by a single ice patch archaeological site, named Thulsoo, which is located north of the Alaska Highway in the high country between the Aishihik-Canyon Lakes and the valley to the east, where the Hutchi Lakes are located. Caribou have been observed in low numbers at or around this ice patch in recent years, and bison, a locally reintroduced species, has also been seen frequenting this ice patch. Numerous historic period indigenous sites have been identified in the Hutchi valley (CAFN Heritage files), while a major cluster of precontact era stone tool sites has been documented in the Aishihik-Canyon Lakes valley to the west; the latter sites are clustered around the narrows between Aishihik and Canyon Lakes. These lower-elevation sites are ca. $8-10 \mathrm{~km}$ (or a few hours' hike) from Thulsoo ice patch. Their size and the type of artifact finds indicate that most of these historic and precontact sites in the Aishihik and Hutchi valleys were campsites, rather than multifamily village sites, the exception being the larger historic era Hutchi village site (Greer, 1996; CAFN and Greer, 1998, 2004).

The third cluster includes the Thandlät ice patch and other small ice patches located in the mountain range between Kusawa and Jojo Lakes, south of the Alaska Highway. While this area is historically and currently known as a good sheep-hunting locale, Champagne and Aishihik Elders reported that caribou were once abundant in this area, but were last seen here in significant numbers in the 1930s (Ned in Cruikshank et al., 1990; Smith, 1997; Hare et al., 2004). It is a few hours' hike, over a distance of 6-7 km, from these ice patches down to the shores of Kusawa and Jojo Lakes, where numerous precontact era archaeological sites have been recorded. Some of the lowerelevation sites also feature historic indigenous occupations. On the basis of their size and the artifact finds, the sites alongside Kusawa and Jojo Lakes have been characterized as campsites (Greer, 1986; Heffner, 1999), and it is hypothesized that these are the base camps from which hunting took place at the Thandlät ice patch.

The Texas Gulch and Sandpiper ice patches are located south of the Alaska Highway, in the mountain block between Rose and Kusawa Lakes. While caribou have not been seen here since the 1930s (Ned in Cruikshank et al., 1990), this area between Rose and Kusawa Lakes continues to be an important sheep hunting area. Not surprisingly, the bones of sheep rather than caribou dominate the faunal collection from these two ice patch sites (Hare et al., 2012). Two clusters of hunting blinds, which have not yet been dated, have also been documented in this mountain block. The blinds are situated alongside trails used by sheep and therefore are interpreted as being used for hunting this species (Greer, 1986). It is roughly $6-7 \mathrm{~km}$, a steep 
hike down and a more strenuous one going uphill, from these patches to Rose Lake, where numerous precontact era archaeological sites have been recorded (Greer, 1981). Precontact era sites have also been identified in lowerelevation settings about the same distance to the west (Greer, 1986). Again, from their size and the type of lithic finds, the sites alongside Rose Lake and Kusawa Lake have been interpreted as shorter-term campsites used when hunting at the nearby ice patch sites. Other types of land-use activities would no doubt have also been undertaken from these lower-elevation sites.

The Alligator and Friday Creek ice patch cluster is located in the mountains northwest of Carcross, southwest of Whitehorse. While these two ice patches are now separate, it appears that they may once have been a large single patch. Two sets of hunting blinds are also situated close to these patches. The first set (JcUu-4), a row of blinds located at the top of the Friday Creek ice patch, appears to have been used to dispatch animals entering or exiting the patch from the ridge above. The second set (JcUu-3) is located across the valley from the Friday Creek ice patch, with the blinds facing south towards the patch (CAFN et al., 2001). Their arrangement - at right angles rather than parallel to the slope-suggests that animals may have been driven from the ice patch to hunters waiting at these blinds. The suggested staging area for hunting trips to the Friday and Alligator ice patches is nearby Alligator Lake (Fig. 3). It is a few hours' hike, roughly $6-7 \mathrm{~km}$, from the patches down to the lake outlet, where a major cluster of precontact era archaeological sites has been identified. These sites have not been investigated in any detail, and artifacts have been collected only on the surface. Nonetheless, from their size (extent of deposits) and the nature of the artifact finds, the Alligator Lake sites have also been interpreted as campsites (Greer, 1981).

The last ice patch, the Granger ice patch, is located southwest of Fish Lake and the city of Whitehorse, a few hours' hike from Fish Lake and the smaller Bonneville Lakes, where many precontact era archaeological sites have been documented (Greer, 1981; Kwanlin Dün First Nation, 1994). We postulate a connection between these sites and the Granger ice patch.

Few if any archaeological sites are known near the ice patches located northeast of Whitehorse. This area is not well known archaeologically, particularly in comparison to the more accessible areas west of Whitehorse, where numerous archaeological sites have been surveyed. The evidence is insufficient to identify a land-use pattern that involved hunting at the ice patches northeast of Whitehorse.

\section{Ancient Cultural Landscapes - Discussion}

The south Yukon ice patch sites appear to be activityspecific sites, locales where long ago hunters went to obtain large game. We propose that hunters likely came to these places on day trips from base camps located in nearby valleys. The size of the sites in the valley bottoms suggests that these hunters were smaller family groups, rather than larger population aggregations with permanent village sites. The ice patch sites therefore can be characterized as specialized hunting sites within an overall subsistence economy based on hunting and fishing by highly mobile family groups. This reconstructed pattern is similar to that followed by the indigenous residents of the southern Yukon during early historic times (1880s-1890s). Whether such a pattern pertained during the many millennia during which hunting took place at the Yukon ice patches is uncertain. Hare et al. (2012) noted that the use of the ice patches as hunting locales appeared to vary over time.

The pattern of land use suggested for the Yukon ice patch sites is generally similar to that understood for ice patch sites documented in Alaska and the Northwest Territories (Andrews et al., 2012; VanderHoek et al., 2012). It appears to differ significantly, however, from the pattern reconstructed (for the more recent millennia, at least) at the Norwegian ice patch sites (Callanan, 2012), which involved an economy that combined farming and hunting at the ice patch sites.

In any discussion of precontact land-use patterns, the ice patches with dung that have not yielded artifacts provide food for thought. Such "negative data" force us to consider why hunting didn't take place at some mountaintop ice patches, despite the presence of caribou evidenced by dung. We can speculate that such patches were less attractive to hunters because they lacked other key subsistence resources or were situated in difficult terrain. Perhaps extremely rich but seasonally dependent resources, such as spawning salmon, were also available at the same time of year caribou visited these ice patches. The potential hunters may have chosen to spend their late summers putting up salmon, rather than hunting caribou at these patches.

We close our discussion on ancient cultural landscapes by noting that we have insights on these matters only at the local level, where we see connections between specific ice patches and nearby sites that may have served as base camps for hunting at these patches. The available archaeological data lack the resolution to determine cultural landscapes at the larger, regional level: we do not know whether the people who hunted at the Ruby Range ice patches over time also hunted at the Thandlät ice patch, for example, or at the ice patches northeast of Whitehorse. We have a poor understanding of these broader patterns of land use and are similarly unable to establish whether and how such patterns might have changed during the many millennia when ancient hunters came to the south Yukon ice patches to obtain caribou.

\section{CONTEMPORARY MEANINGS}

The 2003 discovery of the remains of an ancient moccasin at one of the ice patch sites triggered considerable interest in the First Nations community. The specimen, radiocarbon dated to roughly 1400 years ago, is believed 


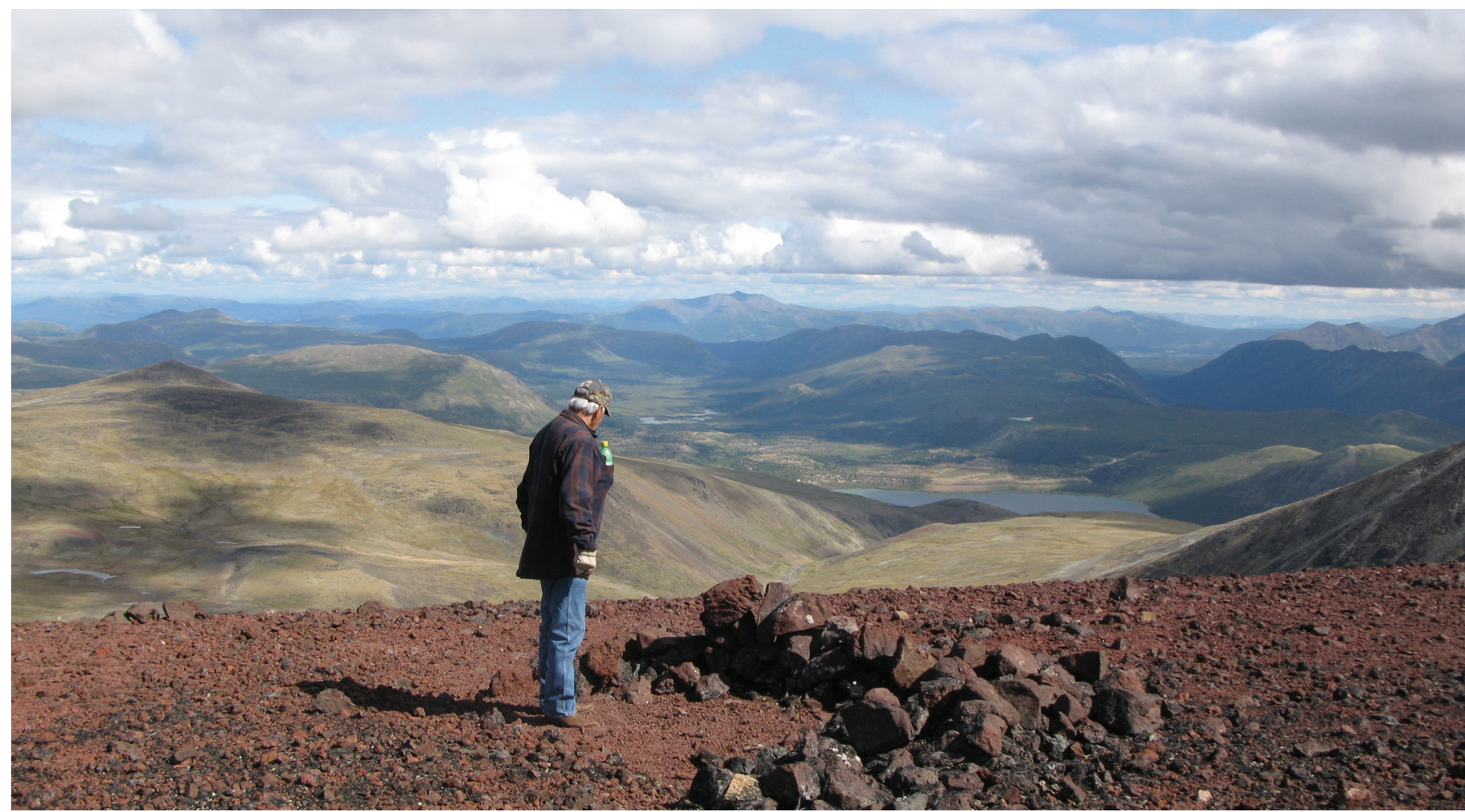

FIG. 3. Carcross/Tagish First Nation Elder Art Johns studies a hunting blind at site JcUu-3, near the Friday Creek and Alligator ice patches. Alligator Lake, the suggested staging area for hunting at these ice patches, shows in the distance. (Photo credit: S. Greer.)

to be the oldest known example of Canadian Indian footwear (Hare et. al., 2012). The moccasin is made in the "old style," with a high top, wrapped and secured around the ankle. Many local First Nations Elders remember this style of moccasin from their youth (CTFN et al., 2005). The find has piqued community members' interest in traditional footwear construction details and design and triggered discussions about changes in moccasin styles.

The moccasin find, along with the hunting tools, has provided many learning opportunities to the First Nations that reflect their broad-based educational approach. The finds have stimulated documentation of relevant vocabulary in the various traditional languages, e.g., arrow $=k^{\prime} \dot{a}$ in Southern Tutchone, chùnèt in Tlingit, $k$ 'a in Tagish; bow $=$ inchi in Southern Tutchone, and sákhs in Tlingit (CTFN et al., 2005). Hands-on learning has also taken place. Atlatl and dart making and dart throwing with the atlatl-throwing device have become regular activities at south Yukon First Nations culture camps. Summer visitors to the Yukon's Beringia Interpretive Centre, located in Whitehorse, can also participate in dart-throwing activities.

The First Nations have hosted two artifact reproduction workshops for adults, in which an artifact reproduction expert shared tips with local craftspeople, many of whom grew up in families known for their hide- or woodworking skills. The craft of stone-tool working has also been re-introduced to the south Yukon First Nations community, and there are now several stone-knappers with growing expertise in this ancient practice. Some of the knapping has been done with obsidian (dùde in Southern Tutchone) from a local source.

In 2004, the Yukon Ice Patch First Nations developed a vision and strategic plan for the ice patch work (CAFN, 2007: Appendix B, p. 2), noting the reasons they considered it important:

It is a window into the world of our ancestors, grounding us in where we've come from; helps renew old ties among our south Yukon First Nations as our common history is explored; provides the opportunity to bring together past and present, old and new, Western science and traditional knowledge; is a source of pride to strengthen our communities and share with others; and reveals lessons about caribou biology, the environmental history of our homelands, and land management concerns.

These First Nations are taking the lead in the oral history and traditional knowledge research efforts related to their peoples' history with caribou, climate change, and the ice patch artifact finds. The Ice Patch Project is recognized as an opportunity to learn about more than ancient artifacts, even if such items are the emotional hook that initially triggers the interest of community members in the project. In addition to the science camps, other forms of outreach have been developed, including two full-colour newsletters (CTFN et al., 2002, 2005) and a colour poster. These outreach documents, which highlight the multidisciplinary 
aspects of the project and the relationship between the finds and climate change, have been well received.

The First Nations have indicated that their goal is to bring together the Western science and traditional knowledge perspectives on these discoveries and the history of caribou in their homelands, including their peoples' spiritual connections to the species. They feel that all these topics must be considered to understand why, as one Elder put it, "the caribou went away" (CTFN et al., 2005).

We believe that the ice patch work has enhanced First Nations understanding of the important connections between people and caribou in their history and culture and improved understanding of the environmental history of our homelands. We note too that consideration of these relationships and how they have changed over time helps First Nations citizens and governments to understand other kinds of resource, landscape, and environmental shifts that are happening in their homelands. These include shifts attributable to climate change, an ever-increasing concern for northern societies.

It has also been suggested that awareness of longer-term environmental change can help communities better understand more local and recent environmental shifts. We know that south Yukon Indian people changed their economy in the not-so-recent past, when near-extirpation of the caribou caused them to shift to moose for subsistence. A better understanding of the strategies employed and challenges met by Native hunters in making this shift could be useful in contemporary game management as south Yukon Indian people and their governments deal with reintroduced species (bison and elk) in their respective cultural landscapes.

While the First Nations governments clearly see the ice patch sites as part of their cultural landscapes, we do not know whether the broader Yukon public shares a similar view. At present, the artifacts from the south Yukon ice patch sites are not on public display in the territory.

\section{CONCLUSIONS}

Today, caribou are a culturally important species only in a limited area of the southern Yukon. However, the oral history accounts of south Yukon Indian people clearly document the important role that caribou played in the history and traditional culture of their ancestors. The evidence from the south Yukon ice patch sites affirms and illustrates these past relationships between people and caribou, bringing the past and present together.

We have used a cultural landscape framework to examine the social context of the Yukon Ice Patch Project, highlighting the involvement of the First Nations in the ongoing studies. We see how these indigenous governments understand the Yukon ice patch sites as part of their contemporary cultural landscapes and have embraced the ice patch archaeological discoveries not only as a manifestation of the material dimension of their past, but also as a means of enhancing the intangible aspects of their heritage.
The research, management, and interpretation of the Yukon ice patches allow Yukon First Nations, both individuals and governments, to strengthen their connection to their heritage and their homelands. Today's indigenous youth, the future hunters in these south Yukon communities, are learning that they are part of a 9000 to 10000 -yearold hunting tradition and gaining an understanding of the many environmental shifts that have taken place in their homelands.

The cultural landscape framework also allows us to see the Yukon ice patch sites as part of a dynamic pattern of ancient land use that included not only these unique paleoecological locales, but also other nearby sites and settings. The ancient pattern of land use at the Yukon ice patch sites is suggested to be similar to that employed at the ice patches in the Northwest Territories and Alaska, but different from that seen at the Norwegian ice patch sites, reported elsewhere in this volume.

\section{ACKNOWLEDGEMENTS}

The Yukon Ice Patch project is a multi-agency and multidisciplinary project involving six First Nations, the Departments of Heritage and Renewable Resources of the Yukon Government, and co-operating researchers affiliated with other institutions. Financial support for project fieldwork has been received from a number of different agencies, including the Government of Yukon (Department of Heritage, Culture and Tourism; Department of Renewable Resources; Executive Office - Northern Strategy Program) and the Government of Canada (Ministry of Environment; Heritage Canada; the Northern Strategy Program). Financial support for other aspects of the project has come from these same agencies, as well as from the six participating First Nations.

The authors acknowledge the Elders who shared their stories about caribou in CAFN traditional territory, particularly Frances Joe and the late Mrs. Annie Ned and Mr. Jimmy G. Smith. We thank Carcross/Tagish First Nation Elder Art Johns for his ongoing interest in and support for the project. We thank the present and past Chief and Council of the Champagne and Aishihik First Nations for their support for and recognition of the importance of the ice patch project and acknowledge the input of our CAFN colleagues Lawrence Joe, Sheila Quock, Paula Banks, and Linaya Workman. We also acknowledge the efforts of the Heritage staff (past and present) of the other south Yukon Ice Patch First Nations, including Pauly Sias, Mark Nelson, Jason Shorty, Tip Evans, Brian Charles, Heather Jones, Susan Mooney, Rae Mombourquette, and John Fingland. Valuable conversations have also taken place with Louise Gordon and Diana French, who work for the Taku River Tlingit First Nation, and with Vera Asp of the Tahltan Heritage Resources Environmental Assessment Team. The Ta'an Kwäch'än Council GIS program provided assistance with the maps, which were put into their final form by Michael Fisher of Edmonton. Natasha Lyons and two other reviewers provided valuable comments on an earlier draft of the manuscript. 


\section{REFERENCES}

Allen, B.̈̈. 2006. Family and traditional Southern Tutchone stories. Recorded and transcribed by Lorraine Allen. Whitehorse: Yukon Native Language Centre.

Allen, J. 1994. Traditional Knowledge Report Aishihik Caribou Recovery Area. Manuscript prepared for Champagne and Aishihik First Nations and Yukon Government Department of Renewable Resources. On file, Champagne and Aishihik First Nations, Heritage Program, Box 5310, Haines Junction, Yukon Y0B $1 \mathrm{~L} 0$.

Andrews, T. 2004. The land is like a book: Cultural landscape management in the Northwest Territories. In: Krupnik, I., Mason, R., and Horton, T., eds. Northern ethnographic landscapes: Perspectives from circumpolar nations. Washington, D.C.: Arctic Studies Center, National Museum of Natural History, Smithsonian Institution. 311-322.

Andrews, T.D., MacKay, G., and Andrew, L. 2012. Archaeological investigations of alpine ice patches in the Selwyn Mountains, Northwest Territories, Canada. Arctic 65(Suppl. 1):1-21.

Ashmore, W., and Knapp, B.A. 1999. Archaeological landscapes: Constructed, conceptualized, ideational. Malden, Massachusetts: Blackwell Publishers.

Basso, K. 1996. Wisdom sits in places: Landscape and language among the Western Apache. Albuquerque: University of New Mexico.

Buggey, S. 1999. An approach to Aboriginal cultural landscapes. Ottawa: Historic Sites and Monuments Board of Canada.

. 2004. An approach to Aboriginal cultural landscapes in circumpolar nations. In: Krupnik, I., Mason, R., and Horton, T., eds. Northern ethnographic landscapes: Perspectives from circumpolar nations. Washington, D.C.: Arctic Studies Center, National Museum of Natural History, Smithsonian Institution. 7-44.

CAFN (Champagne and Aishihik First Nations). 2007. Final report on the 2004/2005 Yukon Ice Patch First Nations strategic planning and communications effort. Report prepared for Canadian Arts and Heritage Sustainability Programme, File \#8406-C70-(04)-1, Department of Canadian Heritage, by Champagne and Aishihik First Nations (Diane Strand, Sheila Greer, and Frances Oles) on behalf of the Yukon Ice Patch First Nations: Carcross-Tagish First Nation, Champagne and Aishihik First Nations, Kluane First Nation, Kwanlin Dun First Nation, Ta'an Kwäch'än Council, Teslin Tlingit Council. Manuscript on file, Champagne and Aishihik First Nations, Heritage Program, Box 5310, Haines Junction, Yukon Y0B 1L0.

CAFN (Champagne and Aishihik First Nations) and Greer, S. 2004. Hutchi Heritage Site, Research and Management 2003. Manuscript on file, Champagne and Aishihik First Nations, Heritage Program, Box 5310, Haines Junction, Yukon Y0B 1L0.

- In press. Wooden artifacts from the Kwädāy Dän Ts'ínchị site and surrounding area: An analytical catalogue. In: Mackie, A.P., Beattie, O., Greer, S., Mackie, K., Hebda, R., and Sendall, K., eds. The Kwädąy Dän Ts'ìnchị discovery. Victoria: Royal British Columbia Museum.
CAFN (Champagne and Aishihik First Nations), Strand, D., and Greer, S. 1999. Caribou in Champagne and Aishihik First Nations traditional territory: A first look at the oral history sources. Paper presented at the Annual Meeting of the Canadian Archaeological Association, Whitehorse. Champagne and Aishihik First Nations, Heritage Program, Box 5310, Haines Junction, Yukon Y0B 1L0.

CAFN (Champagne and Aishihik First Nations), Carcross-Tagish First Nation, Kwanlin Dün First Nation and Greer, S. 2001. Emergency recovery of artifacts from melting ice patches. Final Report to Yukon Community Development Fund, February 2001. Manuscript on file, Champagne and Aishihik First Nations, Heritage Program, Box 5310, Haines Junction, Yukon Y0B 1L0.

Callanan, M. 2012. Central Norwegian snow patch archaeology: Patterns past and present. Arctic 65(Suppl. 1):178-188.

Cruikshank, J. 1974. Through the eyes of strangers. A preliminary survey of land use history in the Yukon during the late nineteenth century. Report to the Yukon Territorial Government and the Yukon Archives. On file with the Department of Tourism and Culture, Government of Yukon, Box 2703, Whitehorse, Yukon Y1A 2 C6.

. 1979. Athapaskan women: Lives and legends. Ottawa: National Museum of Man.

- 1981. Legend and landscape: Convergence of oral and scientific traditions in the Yukon Territory. Arctic Anthropology 18(2):67-93.

. 1982. The gravel magnet: Some social impacts of the Alaska Highway on Yukon Indians. In: Coates, K., ed. The Alaska Highway, Papers of the 40th Anniversary Symposium. Vancouver: University of British Columbia Press. 172-187.

- 1984. Tagish and Tlingit place names in the Southern Lakes Region, Yukon Territory. Canoma 10(1):3-35.

- 1985. Contributions to the oral history of the Kusawa Lake region, Yukon Territory from Mrs. Annie Ned. Manuscript on file, Archaeological Survey of Canada, Canadian Museum of Civilization, 100 Laurier Street, PO Box 3100, Station B, Hull, Quebec J8X 4H2.

1990. Getting the words right: Perspectives on naming and places in Athapaskan oral history. Arctic Anthropology 27(1):52-65.

- 1991. Reading voices. Toronto: Douglas and McIntyre.

2005. Do glaciers listen? Local knowledge, colonial encounters, and social imagination. Vancouver: University of British Columbia Press.

Cruikshank, J., Sidney, A., Smith, K., and Ned, A. 1990. Life lived like a story. Vancouver: University of British Columbia Press.

CTFN (Carcross-Tagish First Nation), and Greer, S. 1995. Skookum stories on the Chilkoot/Dyea Trail. Manuscript prepared for Parks Canada, Whitehorse.

CTFN (Carcross-Tagish First Nation), Champagne and Aishihik First Nations, Kluane First Nation, Kwanlin Dün First Nation). 2002. Ice Patch. Newsletter on file, Champagne and Aishihik First Nations, Heritage Program, Box 5310, Haines Junction, Yukon Y0B 1L0.

CTFN (Carcross-Tagish First Nation), Champagne and Aishihik First Nations, Kluane First Nation, Kwanlin Dün First 
Nation, Ta'an Kwäch'än Council, Teslin Tlingit Council, 2005. Ice Patch, Issue 2. Newsletter on file, Champagne and Aishihik First Nations, Heritage Program, Box 5310, Haines Junction, Yukon Y0B 1L0. www.taan.ca/assets/files/Heritage/ Icepatchnewsletter2005_lowres.pdf. 12 p.

Dove, C.J., Hare, P.G., and Haecker, M. 2005. Identification of ancient feather fragments found in melting alpine ice patches in southern Yukon. Arctic 58(1):38-43.

Farnell, R.G., Hare, P.G., Gotthardt, R.M., Blake, E., Joe, L., Strand, D., and Greer, S. 2000. Southern Yukon alpine ice patches: Climate change records, caribou history, ancient hunters and much more. American Association for the Advancement of Science (Arctic Division) Conference "Arctic Science 2000 - Crossing Borders: Science and Community," 21-24 September 2000, Whitehorse, Yukon.

Farnell, R., Hare, P.G., Blake, E., Bowyer, V., Schweger, C., Greer, S., and Gotthardt, R. 2004. Multidisciplinary investigations of alpine ice patches in southwest Yukon, Canada: Paleoenvironmental and paleobiological investigations. Arctic 57(3):247-259.

French, D., and Greer, S. 2007. Unpublished field notes regarding fieldwork at the ice patch sites in Taku River Tlingit traditional territory. Manuscript in possession of S. Greer.

- 2008. Unpublished field notes regarding fieldwork at the ice patch sites in Taku River Tlingit traditional territory. Manuscript in possession of S. Greer.

Garibaldi, A., and Turner, N. 2004. Cultural keystone species: Implications for conservation and restoration. Ecology and Society 9(3):1 - 18. www.ecologyandsociety.org/vol9/iss3/art1.

Glave, E.J. 1892. The temperamental explorer, Parts 1 and 2. The West 24-28, 64-71. (Reprinted from the Century Magazine, October 1892).

Goldring, P., and Hanks, C. 1991. Commemoration of northern Native history. Historic Sites and Monuments Board of Canada, Report to the Cultural Pluralism Committee, \#199113. Available from National Historic Sites Directorate, Parks Canada, Les Terrasses de la Chaudière, 25 rue Eddy, Hull, Quebec K1A 0M5.

Government of Canada, Government of Yukon, and Champagne, and Aishihik First Nations, 1993. Champagne and Aishihik First Nations Self-Government Agreement. http://www.aadncaandc.gc.ca/eng/1100100030683.

Government of the Northwest Territories. 2007. Living with the land: A manual for documenting cultural landscapes in the Northwest Territories. Yellowknife: Government of the Northwest Territories.

Greer, S.C. 1981. Archaeological survey in the Southern Lakes District, Yukon Territory, Final Report. Manuscript on file, Canadian Museum of Civilization, 100 Laurier Street, PO Box 3100, Station B, Hull, Quebec J8X 4H2.

1986. Kusawa Lake archaeology: Management, research and interpretation. Final Report of the 1985 Kusawa Lake Archaeology Project. Manuscript on file, Canadian Museum of Civilization, 100 Laurier Street, PO Box 3100, Station B, Hull, Quebec J8X 4H2.

- 1996. Archaeology and Heritage Study, 1995 Permit Report, Aishihik Hydroelectric Project relicensing. Manuscript on file, Yukon Heritage Branch, Whitehorse, and Champagne and Aishihik First Nations, Haines Junction.

1997 Sheila Greer notes with Mrs. Frances Joe, Haines Junction, December 6. Manuscript on file, Champagne and Aishihik First Nations, Heritage Program, Box 5310, Haines Junction, Yukon Y0B 1L0.

—. 2004a. Sheila Greer Champagne and Aishihik 2004 field notes (including locational information on the Stanley Creek Ice Patch Site, IlVd-1). Manuscript on file, Champagne and Aishihik First Nations, Heritage Program, Box 5310, Haines Junction, Yukon Y0B 1L0.

- 2004b. Yukon First Nations Heritage Programs. Roundtable discussion, Alaska Anthropological Association Meeting, Whitehorse.

Greer, S.C., Strand, D., and Sias, P. 2011. People, caribou and ice in Dän history and culture - Past dimensions, current connections, Chapter 18. In: Bernard, T., Rosenmeier, L.M., and Farrell, S.L., eds. Ta'n Wetapeksi'k: Understanding from where we come. Proceedings of the 2005 Debert Research Workshop, Debert, Nova Scotia. Truro, Nova Scotia: Eastern Woodland Print Communications. 187-198.

Hanks, C. 1993. Bear Rock, Red Dog Mountain and the Windy Island to Sheldon Lake Trail: Proposals for the commemoration of the cultural heritage of Denedah, and the history of the Shu'tagot'ine. Available from National Historic Sites Directorate, Parks Canada, Les Terrasses de la Chaudière, 25 rue Eddy, Hull, Quebec K1A 0M5.

1996. Narrative and landscape: Grizzly Bear Mountain and Scented Grass Hills as repositories of Sahtu Dene culture. Historic Sites and Monuments Board of Canada, Agenda Papers, \#1996-61. Available from National Historic Sites Directorate, Parks Canada, Les Terrasses de la Chaudière, 25 rue Eddy, Hull, Quebec K1A 0M5.

Hare, P.G., Greer, S., Gotthardt, R., Farnell, R., Bowyer, V., Schweger, C., and Strand, D. 2004. Ethnographic and archaeological investigations of alpine ice patches in southwest Yukon, Canada. Arctic 57(3):260-272.

Hare, P.G., Greer, S., Jones, H., Mombourquette, R., Fingland, J., Nelson, M., Shorty, J., and Evans, T. 2011. The frozen past: The Yukon ice patches. Whitehorse: Government of Yukon.

Hare, P.G., Thomas, C.D., Topper, T.N., and Gotthardt, R.M. 2012. The archaeology of Yukon ice patches: New artifacts, observations, and insights. Arctic 65(Suppl. 1):118-135.

Harington, C.R. 1978. Quaternary vertebrate faunas of Canada and Alaska and their suggested chronological sequence. Syllogeus \#15. Ottawa: National Museums of Canada, National Museum of Natural Sciences.

Heffner, T. 1999. Report of the 1998 Kusawa Bluff Archaeology Project. Manuscript on file, Canadian Museum of Civilization, 100 Laurier Street, PO Box 3100, Station B, Hull, Quebec J8X 4H2.

Heritage Foundation of Newfoundland and Labrador, 2008. What is intangible cultural heritage? www.heritagefoundation.ca.

Hope, A., III, and Thornton, T.F. 2000. Will the time ever come? A Tlingit source book. Alaska Native Knowledge Network. Fairbanks: University of Alaska Fairbanks, Center for CrossCultural Studies. 
Ingold, T. 1996. Hunting and gathering as ways of perceiving the environment. In: Ellen, R., and Fukui, K., eds. Redefining nature: Ecology, culture and domestication. Oxford: Berg. $117-155$.

Jackson, M. 2006. My country is alive: A Southern Tutchone life. With assistance from Beth L. O'Leary. Haines Junction, Yukon: Self-published.

Joe, F. 2009. Transcript of interview with Mrs. Frances Joe, 23 August 2009, James Allen interviewer. Manuscript on file, Champagne and Aishihik First Nations, Heritage Program, Box 5310, Haines Junction, Yukon Y0B 1L0.

Kuhn, T., McFarlane, K.A., Groves, P., Mooers, A.Ø., and Shapiro, B. 2010. Modern and ancient DNA reveal recent partial replacement of caribou in the southwest Yukon. Molecular Ecology 19(7):1312-1323.

Kuzyk, G.W., Russell, D.E., Farnell, R.S., Gotthardt, R.M., Hare, G.P., and Blake, E. 1999. In pursuit of prehistoric caribou on Thandlät, southern Yukon. Arctic 52(2):214-219.

Kwanlin Dün First Nation 1994. Łu Zil Män, Fish Lake, uncovering the past. (Ruth Gotthardt and Greg Hare, writers). Whitehorse: Yukon Heritage Branch.

Leer, J., Hitch, D., and Ritter, J., comp. 2001. Interior Tlingit noun dictionary: The dialects spoken by Tlingit Elders of Carcross and Teslin, Yukon, and Atlin, British Columbia. Whitehorse: Yukon Native Language Centre.

McClellan, C. 1975. My old people say: An ethnographic survey of southern Yukon Territory, 2 vols. Publications in Ethnology 6. Ottawa: National Museums of Canada. (Reprinted 2001 as Mercury Series, Canadian Ethnology Service Paper 137. Hull, Quebec: Canadian Museum of Civilization.)

- 1981a. Inland Tlingit. In: Helm, J., ed. Handbook of North American Indians: Vol. 6, Subarctic. Washington D.C.: Smithsonian Institution. 469-480.

- 1981b. Tagish. In: Helm, J., ed. Handbook of North American Indians: Vol. 6, Subarctic. Washington D.C.: Smithsonian Institution. 481-492.

. 1981c. Tutchone. In: Helm, J., ed. Handbook of North American Indians: Vol. 6, Subarctic. Washington D.C.: Smithsonian Institution. 493-505.

2007a. My old people's stories: A legacy for Yukon First

Nations. Part I: Southern Tutchone Narrators. Hudé Hudän Series, Occasional Papers in Yukon History 5. Whitehorse: Cultural Services Branch, Government of the Yukon.

2007b. My old people's stories: A legacy for Yukon

First Nations. Part II: Tagish Narrators. Hudé Hudän Series, Occasional Papers in Yukon History 5. Whitehorse: Cultural Services Branch, Government of the Yukon.

2007c. My old people's stories: A legacy for Yukon First Nations. Part III: Inland Tlingit Narrators. Hudé Hudän Series, Occasional Papers in Yukon History 5. Whitehorse: Cultural Services Branch, Government of the Yukon.

McClellan, C., and Denniston, G. 1981. Environment and culture in the Cordillera. In: Helm, J., ed. Handbook of North American Indians: Vol. 6, Subarctic. Washington D.C.: Smithsonian Institution. $372-386$.
McClellan, C., Birckel, L., Bringhurst, R., Fall, J.A., McCarthy, C., and Sheppard, J.R. 1987. Part of the land, part of the water: A history of Yukon Indians. Vancouver: Douglas and McIntyre.

Mombourquette, R. 2010. People, caribou and ice: Yukon First Nations and the Yukon ice patch studies. Presenter on behalf of Carcross/Tagish First Nation, Champagne and Aishihik First Nations, Kluane First Nation, Kwanlin Dün First Nation, Ta'an Kwäch'än Council, and Teslin Tlingit Council at "Frozen Pasts," 2nd International Glacial Archaeology Symposium, 5-7 October 2010, Trondheim, Norway.

Ned, A. 1982. Old people in those days, they told their story all the time. Whitehorse: Yukon Native Language Centre.

Oberg, K. 1973. The social economy of the Tlingit Indians. Vancouver: J.J. Douglas Ltd.

O'Leary, B.L. 1992. Salmon and storage: Southern Tutchone use of an abundant resource. Occasional Papers in Archaeology 2. Whitehorse: Heritage Branch, Government of Yukon.

Oswald, E.T., and Senyk, J.P. 1977. Ecoregions of Yukon Territory. Victoria, British Columbia: Environment Canada, Canadian Forestry Service, Pacific Forest Research Centre.

Parks Canada. 2012. An approach to Aboriginal cultural landscapes. http://www.pc.gc.ca/docs/r/pca-acl/index.aspx.

Rössler, M. 2003. Cultural landscapes: The challenges of conservation. World Heritage Papers 7. In: Linking nature and culture: World heritage cultural landscapes. Paris: UNESCO. $10-15$.

Sauer, C.O. 1967. Land and life: A selection of the writings of Carl Ortwin Sauer. Berkeley: University of California Press.

. 2009. Carl Sauer on culture and landscape: Readings and commentaries. Baton Rouge: Louisiana State University Press.

Schwatka, F. 1996. Schwatka's last search: The New York Ledger Expedition through unknown Alaska and British America: including the Journal of Charles Willard Hayes, 1891. Edited by Arland S. Harris. Fairbanks: University of Alaska Press.

Sidney, A. 1980. Place names of the Tagish Region, southern Yukon. Whitehorse: Yukon Native Languages Project, Council for Yukon Indians.

1982. Tagish Tlaagu, Tagish stories. Whitehorse: Yukon Native Languages Project, Council for Yukon Indians.

Sidney, A., Smith, K., and Dawson, R. 1979. My stories are my wealth. Whitehorse: Council for Yukon Indians.

Smith, J.G. 1997. Communications regarding caribou to Sarah Gaunt and Diane Strand. Manuscript on file, Champagne and Aishihik First Nations, Heritage Program, Box 5310, Haines Junction, Yukon Y0B 1L0.

Smith, K. 1982. Nindal Kwadindur, I'm going to tell you a story. Recorded by J. Cruikshank. Whitehorse: Council for Yukon Indians and Government of Yukon.

Smith, L., and Akagawa, N., eds. 2009. Intangible heritage: Key issues in cultural heritage. Oxon and New York: Routledge.

Slobodin, R. 1981. Kutchin. In: Helm, J., ed. Handbook of North American Indians: Vol. 6, Subarctic. Washington D.C.: Smithsonian Institution. 514-532.

Thornton, T.F., with contributions by McBride, D., Gupta, S., Carcross/Tagish First Nation, Chilkat Indian Village, Chilkoot 
Indian Association and Skagway Traditional Council. 2004. Klondike Gold Rush National Historical Park ethnographic overview and assessment. U.S. National Parks Service.

Tlen, D.L. 1993. Kluane Southern Tutchone Glossary (English to Southern Tutchone). Occasional Papers of the Northern Research Institute, Monograph \#1. Whitehorse.

UNESCO (United Nations Educational, Scientific and Cultural Organization). n.d. What is intangible cultural heritage? www. unesco.org/culture/ich/index.php?pg $=00002$.

VanderHoek, R., Dixon, E.J., Jarman, N.L., and Tedor, R.M. 2012. Ice patch archeology in Alaska: 2000-2010. Arctic 65(Suppl. 1):153-164.
Workman, M., compiler and translator. 2000. Kwäday Kwändür, traditional Southern Tutchone stories, as told by Marge Jackson, Mary Jacquot, Jessie Joe, Jimmy Copper Joe, Copper Lily Johnson and Jessie Jonathan. Whitehorse: Yukon Native Language Centre.

Youngman, P.M. 1975. Mammals of the Yukon Territory. Ottawa: National Museums of Canada, National Museum of Natural Sciences.

Yukon Ecoregions Working Group. 2003. Ecoregions of the Yukon Territory: Biophysical properties of Yukon landscapes. Edited by C.A.S. Smith, J.C. Meikle and C.F. Roots. Agriculture and Agri-Food Canada.

Zazula, G., and Froese, D. 2011. Ice Age Klondike, fossil treasures from the frozen ground. Whitehorse: Government of Yukon. 